\title{
Development process of content validity of pedagogical knowledge assessment in swimming
}

\section{Processo de desenvolvimento da validade de conteúdo da avaliação do conhecimento pedagógico na natação}

\author{
Gabriella Nelli Monteiro ${ }^{1}$ \\ (D) https://orcid.org/0000-0001-6656-4560 \\ Schelyne Ribas ${ }^{1}$ \\ (D) https://orcid.org/0000-0001-7408-7784 \\ Francisco Jiménez Jiménez² \\ (D) https://orcid.org/0000-0002-2817-5860 \\ Tatiane Mazzardo ${ }^{1}$ \\ (D) https://orcid.org/0000-0001-5732-1540 \\ Nayanne Dias Araújo ${ }^{1}$ \\ (D) https://orcid.org/0000-0002-0983-0380 \\ Layla Maria Campos Aburachid ${ }^{1}$ \\ (D) https://orcid.org/0000-0002-0116-9014
}

Abstract - This study aimed to validate the content of items regarding an instrument of assessment of substantive contents, its organization and forms of practice, and pedagogical feedback in swimming sessions by the use of the coefficient of content validity (CVC). This analysis encompass the validation of instruments in a theoretical way, which has generated a grid of occurrences on items related to pedagogical knowledge of teaching and learning contents in swimming sessions. Three examiners took part in the sample. The three of them hold active experience of at least ten years in the teaching of swimming and have assessed 31 items according to the agreement related to criteria of clarity of language, practical relevance, theoretical relevance, and dimension. According to the minimum accepted agreement for the $\mathrm{CVCi} \geq 0.7$, three items from the grid were excluded, for they presented results under the expected regarding practical and theoretical relevance. Then, a new CVCtotal was measured, considering the 28 remaining items. CVCtotal was satisfactory in the three criteria, which demonstrated that the items were described clearly, they are adequate for the teaching and learning of swimming, and indicate to be in compliance with the competences the coach must have on the pedagogical knowledge when it comes to swimming. Subdivided in the dimensions of: nature of the task, organization and types of practice, pedagogical feedback and its subdimensions (objective, type, direction, and reference), the 28 items will pedagogically assist the swimming coach as to contents, organization of practice, and feedback.

Key words: Psychometrics; Swimming; Validation study.

Resumo - Este estudo teve o objetivo de validar o conteúdo dos itens de um instrumento de avaliação dos conteúdos substantivos, suas organizaçôes e formas de prática e do feedback pedagógico para a natação por meio do coeficiente de validade de conteúdo (CVC). Esta análise se reteve ao polo teórico da validação de instrumentos, que gerou uma grelha de ocorrências sobre itens relativos ao conhecimento pedagógico de conteúdo do ensino e aprendizagem da natação. A amostra foi composta por três avaliadores, com experiência ativa de no mínimo 10 anos na área do ensino da natação que julgaram 31 itens quanto a concordância dos critérios de clareza da linguagem, pertinência prática, relevância teórica e da dimensão teórica. Seguindo o critério de concordância minima aceitável para - CVCi $i \geq 0,7$ três itens da grelha foram excluidos, pois apresentaram resultados abaixo do esperado nos critérios pertinência prática e relevância teórica. Em seguida um novo CVCtotal foi mensurado, levando-se em consideração 28 itens restantes. Nos três critérios o CVCtotal foi satisfatório, demonstrando que os itens foram descritos de forma clara, que se adequam ao ensino e aprendizagem da natação e indicam estar de acordo com as competências que o professor deve ter sobre o conbecimento pedagógico no ensino desse esporte. Subdivididos nas dimensôes de natureza da tarefa, organização e formas de prática e feedback pedagógico e suas subdimensöes objetivo, forma, direçâa e referencial, os 28 itens darão auxílio como meio pedagógico ao professor de natação quanto aos conteúdos aplicados, sua organização da prática e seus feedbacks.

Palavras-chave: Estudo de validação; Natação; Psicometria.
1 Federal University of Mato Grosso, Cuiabá, MT. Brazil

2 University of La Laguna. Santa Cruz de Tenerife. Espanha.

Received: March 09, 2020 Accepted: May 18, 2020

How to cite this article Monteiro GN, Ribas S, Jiménez FJ, Mazzardo T, Araújo ND, Aburachid LMC. Development process of content validity of pedagogical knowledge assessment in swimming. Rev Bras Cineantropom Desempenho Hum 2020, 22:e72071. DOI: http://dx.doi.org/10.1590/19800037.2020v22e72071

Copyright: This work is licensed under a Creative Commons Attribution 4.0 International License. 


\section{INTRODUCTION}

Pedagogic knowledge of the content can be defined as processual knowledge, "how to do", which allows the educator to perform adaptations to descriptive knowledge, "what to do", to understand the development of student's knowledge ${ }^{1}$. It allows the transformation of knowledge of the content in different ways of appropriate knowledge to promote student's apprenticeship ${ }^{2}$.

By promoting a linkage between student and assignment (content transmitted), the educator knows the features of the subjects, their expectations and necessities, and adds to the acquired experiences in order to create a proper atmosphere of motivation for apprenticeship ${ }^{3}$.

When it comes to swimming, as in any other sports, it is primal that the educator knows the contents associated with this very practice and the factor that influence some quality apprenticeship. Studies related to the teaching of swimming focus on the identification of methods applied by educator in their classes, mainly through interviews, even though there are no driven studies to determine the predominance of organization and ways of practice during classes. The only exception is the study conducted by Pestana ${ }^{4}$, which classifies pedagogical feedback in the teaching of swimming, with no use of validated instrument for such thing though.

Costa's ${ }^{5}$ review article points that until 2009, out of 218 articles on swimming, $14.7 \%$ fit teaching area, $27.5 \%$ fit therapy area, and $57.8 \%$ are related to biomechanics. Regarding the context of teaching, out of 32 selected articles, only nine are studies on teaching-learning in swimming, and six approach teaching related to professor/coach attitude and career, and three of them focused on questions related to apprenticeship of strokes.

According to Aburachid and $\mathrm{Greco}^{6}$, there is a growing need of having validated instruments to measure, calculate, and assess actions or behaviors within the subareas from the Science of Sports. The elaboration and validation of this instrument were based in Psychometrics ${ }^{7}$, an area in psychology that measures the researchers for the verification of scientific hypothesis through items, built from the representativeness of a finite universe of behaviors (constructs).

The content validation of the instrument happened from the construction of a grid of occurrences on items related to pedagogical knowledge of teaching content, and apprenticeship in swimming, based on the theoretical field of a psychometric model of instrumental elaboration by Pasquali ${ }^{7}$, and sustained by the theoretical fundaments in literature and the agreement of experts responsible for the investigated construct.

So far, there are four studies, in literature, that have validated instruments of assessment of pedagogical knowledge of content: in artistic gymnastics $^{8}$, volleyball $^{9}$, soccer ${ }^{10}$, and hockey ${ }^{11}$. Specifically in swimming ${ }^{4}$, the study has not utilized the validated instrument to point a frequency of pedagogic feedback in a communicative phase between coach and athlete.

Furthermore, the instruments turned to teaching and learning in swimming assess aquatic motor competence ${ }^{12}$, aquaticity in humans ${ }^{13}$, 
adaptation to aquatic environment, and pedagogical progression of the content ${ }^{14}$. So far, no instrument on the identification on the pedagogical knowledge to the contents of a swimming instructor has been validated, which made development and validation necessary, at first regarding content, of an instrument that verifies this professor's knowledge in order to assess their practice.

A discerning identification of indicators of pedagogical knowledge of content, as proposed, aims to allow that, in the future, content analysis in swimming becomes meaningful knowledge and absorbable for students, which enables professor's reflection on their competence ${ }^{15}$, regarding teaching in swimming. It is in the conception and development of tasks that teaching competence can be observed ${ }^{16}$.

Thereby, this study aimed to develop and validate content, an instrument of assessment of pedagogical knowledge in swimming.

\section{METHODS}

In order to obtain theoretical validation of the instrument, we followed the steps based on Hernández-Nieto ${ }^{17}$, who points out the need of three to five experts to conduct the validation. Thus, we invited five experts to participate, which characterizes the sample by convenience ${ }^{18}$, and two of them declined our invitation. Nonetheless, there were still three of them to conduct the validation. The criterion of selection of the experts, according to Balbinotti et al. ${ }^{19}$, indicates that none of them had previously participated in any other part of the research, hold an active experience of at least ten years, and teach swimming at a college degree. Two of the professors hold a doctor degree obtained in national public universities and the third one is an expert in sports training, professor in a private university, member of the Brazilian Academy of Coaches (original in Portuguese, Academia Brasileira de Treinadores), as also a coach of a swimming team in a competitive level. All experts have signed the Informed Consent Form (ICF) and the project was approved by the Research Ethics Committee with human beings of the Federal University of Mato Grosso (Universidade Federal de Mato Grosso, in Portuguese), under number 1.868.086.

For the reliability of data, six swimming instructors joined this study, and all of them are majored in Physical Education. The filming of two classes of each professor, having the study of Pestana ${ }^{4}$ as a reference, equaled to twelve classes (468.98 minutes of pedagogical performance effectively). By using the items previously validated in the grid of study, through the viewing of the videos, the researcher registered the frequency of the occurrence of pedagogical actions, which generated 8,532 pieces of information collected for the seven dimensions. We used such pieces of information in order to determine reliability of data.

As a way to complement information, after a survey conducted along with the Regional Council of Physical Education (CREF, in Brazil), nine swimming schools were listed in the city of Cuiaba, capital state of Mato 
Grosso. However, one of the institutions did not authorize the study, and two others, because of renovations in the pool and an injured instructor, could not take part in the research. Therefore, all possible gyms in town and their respective instructors took part in the study.

\section{Validation Procedures}

The initial step was the construction of the items that reference in the organizational chart for the elaboration of the tests proposed by Pasquali ${ }^{7}$. The first of them, named as psychological system (step one) defines system as something observable, measurable, and representative in the universe of scientific interest, and was, in this study, identified as "pedagogical knowledge of content". The properties (step two) are the objects of measurement that characterize the system, and go through the process of limiting of specific aspects, characterized in the study as the attributes "nature of the task", "pedagogical feedback", "organization of practice", and "types of practice".

The dimensionality of the attributes (step three) represents the internal structure of the validated instrument. In this study, 31 items belonging to seven dimensions that, named holistically, compose the pedagogical knowledge of the content, as proposed by Ramos et al. ${ }^{1}$ and Tani et al. ${ }^{3}$.

The definitions (step four) involve scientific and substantiated clarification of the constitutive definition that characterizes and limits the construct in each of its dimensions. The other definition is operational and it is supposed to determine how researchers will turn the abstract concept of the construct into a concrete one, likely to be measured. This study comprised those aforementioned definitions regarding studies in artistic gymnastics ${ }^{8}$ and volleyball ${ }^{9}$, concerning pedagogical feedback and nature of the task. The organizations and types of practice proposed are according to the concepts by Ugrinowitsch and Benda ${ }^{20}$. Box 1 presents the dimensions and their categories analyzed by the experts in the chart, which contain the concepts and practical examples of swimming used to better comprehend the assessment of the items.

At step five, so called operationalization of the construct, the methodological tool of assessment followed the procedures as proposed by Hernandez-Nieto ${ }^{18}$, who points out the need of three to five experts to conduct the validation of the items, according to what we have previously mentioned in the sample.

For reliability of data, we have included the twelve videos of classes, one by one, in MatchVision Studio Premium, the software we chose to analyze the systematic observation, and which allowed us to quantify the frequency of occurrence of pedagogical actions in the items previously validated by the content in a resulting spreadsheet.

\section{Data Analysis}

For the analysis of those 31 items we proposed, we have used content validity, presented by Pasquali ${ }^{7}$ with the application of the CVC calculation by Hernandez-Nieto ${ }^{17}$. The experts pointed out that in a Likert scale from 
Box 1. Constructs defined by dimensions

\begin{tabular}{|c|c|c|c|}
\hline \multicolumn{4}{|l|}{ Nature of the task (1) } \\
\hline \multicolumn{4}{|l|}{$\begin{array}{l}\text { Technique } \\
\text { Physical and rules } \\
\text { Undefined Information }\end{array}$} \\
\hline \multicolumn{4}{|l|}{ Pedagogical feedback (2) } \\
\hline $\begin{array}{l}\text { Objective (2) } \\
\text { Prescritive(P) } \\
\text { Descriptive Correction (DC) } \\
\text { Descriptive Error (DE) } \\
\text { Evaluative Positive (EP) } \\
\text { Evaluative Nevative (EN) } \\
\text { Interrogative (I) }\end{array}$ & $\begin{array}{l}\text { Type (3) } \\
\text { Kinesthetic (K) } \\
\text { Visual (VI) } \\
\text { Verbal (VE) } \\
\text { Verbal/Visual } \\
\quad \text { VIVE) } \\
\text { Verbal/Kinesthetic } \\
\quad \text { VEQ) } \\
\text { Visual/Kinesthetic } \\
\text { (VIQ) } \\
\text { Verbal/Visual / } \\
\text { Kinesthetic (VEVIQ) }\end{array}$ & $\begin{array}{l}\text { Direction (4) } \\
\text { Individual (ID) } \\
\text { In pair (EP) } \\
\text { Group (AC) }\end{array}$ & $\begin{array}{l}\text { Criterion (5) } \\
\text { Performance Criterion (PC) } \\
\text { Result Criterion (RC) }\end{array}$ \\
\hline \multicolumn{4}{|l|}{ Organization of practice (6) } \\
\hline \multicolumn{4}{|l|}{$\begin{array}{l}\text { As a block } \\
\text { In a series } \\
\text { Varied } \\
\text { Constant }\end{array}$} \\
\hline \multicolumn{4}{|l|}{ Types of practice (7) } \\
\hline $\begin{array}{l}\text { A a whole } \\
\text { Fractioned } \\
\text { Segmented } \\
\text { Simplified }\end{array}$ & & & \\
\hline
\end{tabular}

01 (one - poor) to 05 (five - excellent) points its compliance as criteria of clarity of language, practice relevance, and theoretical relevance. The values of agreement to determine acceptable levels must be higher than .70 for each one of the items $\left(\mathrm{CVC}_{\mathrm{c}}\right)$ and for the final general value $(\mathrm{CVCt})^{7}$.

When it comes to theoretical dimension - a procedure that determines each item's dimension - we have asked the experts which dimension (nature of the task, pedagogical feedback, organization of practice, and types of practice); and which category of the pedagogical feedback dimension (objective, type, direction, and reference), each one of the items belonged to, which allowed us to assess reliability through objectivity, making use of the interobserver agreement (IOA).

As this instrument is not a questionnaire, but a filling chart of occurrences of pedagogical actions referred to pedagogical knowledge of content given by the instructor in the swimming classes, we have obtained reliability of data based on the 8,532 pieces of collected information. Then, we have stablished intra- and interobserver reliability for class observations, via Cohen's kappa coefficient. According to Tabachnick e Fidell ${ }^{21}$, for this analysis it has attended $10 \%$ of the videos. Out of 12 videos of classes, two observers analyzed and reanalyzed two classes given by a professor.

\section{RESULTS}

Presented results are from CVCtotal $\geq .7$ for the three criteria of validation assessed by the experts and Box 2 exposes excluded items. 
Box 2. Number of items kept and discarded in the process of content validation in the chart of assessment for the teaching of swimming.

\begin{tabular}{|c|c|c|c|}
\hline 31 & 31 & 28 & 28 \\
\hline $\begin{array}{l}\text { Total of items divided by } \\
\text { dimensions: } \\
\text { Nature of the task; } \\
\text { Objective; } \\
\text { Type; } \\
\text { Direction; } \\
\text { Reference; } \\
\text { Organization of practice; } \\
\text { Types of practice. }\end{array}$ & $\begin{array}{l}\text { Clarity of language: } \\
\text { CVCt: .88 }\end{array}$ & $\begin{array}{l}\text { Practice relevance: } \\
\text { Nature of the task: item } 03 \\
\text { (.43); } \\
\text { Objective: item } 09 \text { (.43); } \\
\text { Direction: item } 20 \text { (.63); } \\
\\
\text { CVCt: .84 }\end{array}$ & $\begin{array}{l}\text { Theoretical relevance: } \\
\text { Nature of the task: item } 03 \\
\text { (.56); } \\
\text { Objective: item } 09(.36) ; \\
\text { Direction: item } 20(.63) ; \\
\\
\text { CVCt: .86 }\end{array}$ \\
\hline
\end{tabular}

Out of 31 items, the three ones that we excluded did not reach CVCitem higher than .7, within the following criteria: practice relevance and theoretical relevance. They were item 03, undefined information of the dimension "nature" of substantive content; item 09 , penalty of dimension "objective"; item 20, feedback given to groups related to dimension "direction". Despite the exclusion of these three items, the experts did not suggest any changes regarding any of the remaining items.

After the exclusion of the items, we measured a new CVCtotal, considering the 28 remaining items, evidenced in Table 1.

Table 1. Results of CVC for criteria of validation.

\begin{tabular}{lccc}
\hline Criteria of validation & Items with CVCi<.7 & Items with CVCi $\geq .7$ & Value of CVCt \\
\hline Clarity of language & 0 & 28 & .89 \\
Practice relevance & 3 & 28 & .88 \\
Relevância teórica & 3 & 28 & .90 \\
\hline
\end{tabular}

Note. CVCi: content validity coefficient per item; CVCt: total content validity coefficient of criterion.

In those three criteria, CVCt was satisfactory, which demonstrated that the items were described in a clear way (clarity of language); that they are adequate to the teaching and learning in swimming as its relevance in the practice (practice relevance); and indicate to be in compliance with the necessary competences to the educators about the pedagogical knowledge for the teaching of swimming corresponding to literature (theoretical relevance).

In order to determine theoretical dimension, after content validation, now with 28 items, the interobserver agreement (IOA) value was $92.8 \%$. Despite the allocation of items concerning dimensions (nature of the task, pedagogical feedback, organization of the practice, and types of practice) have had an agreement of $100 \%$, when it came to the subdivision in the categories related to pedagogical feedback (objective, type, direction, and reference), two experts pointed out that two items belonged to type, but also direction.

Finally, collected data reliability presented, by the use of the Cohen's kappa coefficient, values of .95 and .84 for the intra- and interobservers, respectively.

\section{DISCUSSION}

This study had, as a goal, to develop and validate the content of an in- 
strument for the assessment of pedagogical knowledge in swimming. According to the assessment of experts, the items, in their majority, were representative for the competences on the pedagogical knowledge for the teaching of swimming. Experts justified three highlighted items: undefined information of the dimension "nature" of substantive content (03); penalty of dimension "objective" (09); and (20) feedback given to groups related to dimension "direction", as situations that must not happen when it comes to the teaching-learning process and to the characteristics of individual sport that the practice presents.

As to item 03, undefined information, which means information issued by the instructor with no particular reference to any specific content in swimming, experts have discarded it because they believe that, during class, there is no issued information by the instructors that do not correlate with the contents or with pedagogical support regarding teaching and learning in swimming.

As to item 09, penalty, the experts stated that punitive moments are not adequate during classes; instructors must search less sharp ways to deal with students' disobedience. Pecaver et al. ${ }^{22}$ point out that one of the difficulties faced by swimming instructors of students from four to eleven years old in Slovenian schools is that they are stubborn, audacious, and disobedient, which brings the need of a punitive feedback in class, a result that goes against experts' opinion in this stage of teaching and learning in swimming.

Finally item 20, the feedback given to groups. Besides the fact that it is an individual practice, experts have said that feedbacks must not be issued by more than two people, for they consider the principle of biologic individuality of each student, which leans to the fact that they must be directed. Such notes corroborate the characteristics of individual sports which, according to Vancine et al. ${ }^{23}$, the focus must the technical gesture, centered in the individual performance.

Regarding the use of auxiliary accessories during the learning process in swimming, two experts pointed that they partially agree with the use of these accessories, as long as the instructor knows why and how to use them. This way, instructors neither become dependent nor stimulate students to become dependent on these accessories within the teaching and learning process in swimming. The third expert rejected them at this stage, though approved them at other ones, and reported them as necessary for the learning or correction of some technique. The study rebuts the authors Fortes et al. ${ }^{24}$ who verified the preference of 70 children for the pool mat and the noodle (water $\log$ ), showing that the activities that used these materials the most were the segmented ones that uses the arm, leg, propulsion, and diving. These are usual swimming activities that when executed with these accessories can make the class more joyful and less boring for the students.

The studies that built and validated instruments of pedagogical knowledge of content in other practices also started from the alignment of theory and methodologies in literature, and made use of three experts during the assessment to prove whether the dimensions and categories covered the totality of proposed problems ${ }^{8-11}$. 
In order to make meaningful constructs, $\mathrm{Pasquali}^{7}$ preconizes that a test must contain at least twenty items, and the psychometrics evidences that the validation process must start with three times more items so they can be disregarded when not constituted from a theory. However, when this process is based on a theory, it is not necessary to start with more than $10 \%$ beyond the twenty selected items, as this has happened in this study.

Besides, statistical procedures for content validity by Hernández$\mathrm{Nieto}^{17}$, as well as in this study, and also used in some other researches in Physical Education, most of them to assess sports abilities, as in the study by Aburachid and $\mathrm{Greco}^{25}$ in the tactic knowledge test in tennis; the one by Morales et al. ${ }^{26}$ in the processual tactic knowledge test in basketball; the one by Greco et al. ${ }^{27}$ in the processual tactic knowledge test - sports guidance; and by Pedrosa et al. ${ }^{28}$ in the catalog containing 76 judo exercises, which demonstrates the efficiency in the emergence of satisfactory and renowned statistical results by the academic community.

As to theoretical dimension, besides the adherence of experts in $100 \%$ regarding the dimensions in which the items have been allocated, in the subdivision of pedagogical feedback (objective, type, direction, and reference) only two items (7.8\%) were ambiguously classified; belonging to type, but also to direction. In the study of validation of content in tennis by Aburachid and $\mathrm{Greco}^{25}$, out of 192 video scenes of matches, only two of them were allocated in distinct theoretical dimensions (technical-tactical swing volley actions, approach shots, passing shots, and volley) and with the use of the Half-test Correlation and the Spearman Brown Prophecy Formula, the obtained result was of .99. However, as in this study, and as like Balbinotti et al. ${ }^{17}$, we have kept the items that experts classified as ambiguous. It happened because the types of kinesthetic feedback and visual/kinesthetic feedback occur individually in their majority.

According to Landis and $\mathrm{Koch}^{29}$ classification, the reliability of data revealed, by the Cohen's kappa coefficient, a perfect agreement.

The limitations of the studies rely on the quantitative aspect of instructors who accepted to have their classes filmed and then analyzed so then we could obtain pieces of information resulting from the frequency of occurrences obtained via validated items in the grid. Out of nine institutions registered in the Regional Council of Physical Education in the city of Cuiaba, six have agreed to take part in the research. Another difficulty we had was the provision of financial resources for data collection throughout the state of Mato Grosso, which refused a possibility of conducting a wider study.

We recommend that, for future studies, the application of the instrument of assessment of organizations and types of practice and pedagogical feedback is performed in other regions. It should be considered because of the continental size of the country and the great amount of swimming students that, according to the Ministry of Sports, is the third most practice as a first sport (4.9\%), which comes behind soccer (59.8\%) and volleyball $(9.7 \%)^{30}$. 


\section{CONCLUSION}

This study confirms the validation of content for a satisfactory number of items, which generates the instrument of assessment of organizations and types of practice and pedagogical feedback - the APFP, in Portuguese, for swimming (APPENDIX 1) after the fulfillment of the six stages due to the theoretical procedures of validation of psychometric tests. It is important to highlight that this has been the first stage of the validation process of the instrument. Other analysis must be conducted so it can be effectively said this instrument is valid as well as its construct, or further types of validity (criterion, predictive, construct, and others), according to researchers' objective in further studies.

The APFP for swimming supports it pedagogically, in a greater involvement in the teaching and learning process in which instructors apply in classes and identify how they apply the contents, how they organize their practice and transmit their feedbacks, which also allow to collaborate along with field studies that will assist in the determination of teaching methods, types of instruction, and feedback currently applied in the swimming practice.

\section{COMPLIANCE WITH ETHICAL STANDARDS}

\section{Financing}

This study had the financial support from CAPES, the Coordination for the Improvement of Higher Education, and FAPEMAT, the Foundation for Research Support of the state of Mato Grosso. 2016-2017, Cuiabá, state of Mato Grosso, Brazil.

\section{Ethical Aspects}

The ethical approval was obtained from the Human Research Ethics Committee by the Federal University of Mato Grosso and obtained consolidated report number 1.868 .086 in $12 / 15 / 2016$, and the protocol was written according to patterns established by the Declaration of Helsinki.

\section{Conflict of interests}

The authors of this study have no conflict of interests to declare.

\section{Contribution from authors}

Conception and limiting of the experiment: GNM, LMCA. Accomplishment of the experiments: GNM, LMCA, TM, NDA. Data analysis: GNM, LMCA, TM, NDA, SRS. Contribution with reagents/facilities for research/tools of analysis: GNM, LMCA, SRS. Writing of the article: GNM, LMCA, FJJ. All of the authors have read and approved the final version of this research. 


\section{REFERENCES}

1. Ramos V, Graça ABS, Nascimento JVD. The pedagogical content knowledge: structure and implications to physical education teacher education. Rev Bra Educ Fís Esporte 2008; 22(2):161-71.

2. Grossman PL, Wilson SM, Shulman LS. Teachers of Substance: Subject Matter Knowledge for Teaching. Profr Rev Curríc Form Profr 2005; 9(2):01-25.

3. Tani G, Basso L, Corrêa UC. The teaching of sport to children and youth: considerations about a forgotten phase of motor development. Rev Bras Educ Fís Esporte 2012; 26(2):339-350.

4. Pestana G. Communicative success in sports: study of feedback of instructor and athlete within the teaching of sports. Horizonte 2006; 21(124):29-35.

5. Costa PHL. Pedagogy in swimming: a preliminar systematic review. Rev Mackenzie Educ Fís Esporte 2010; 9(1):50-54.

6. Aburachid LMC, Greco PJ. Validation process of a tactical declarative knowledge test in tennis. J Phys Educ 2010; 21(4):603-610.

7. Pasquali L. Psychologial instrumentalization. Fundamentals and practice. Porto Alegre: Artmed; 2010.

8. Aleixo IMS, Vieira MM. Feedback on the instruction of Artistic Gymnastics. Motrici 2012; 8(S2):849-859.

9. Pereira MF, Mesquita RI, Graça AS, Moreno AMP. Multidimensional analysis of pedagogical feedback in volleyball training setting. Rev Int Med Cienc Act Fís Deporte 2010; 10(38):181-202.

10. Santos CA, Rodrigues JJF. The soccer coach instruction. Comparative analysis between the preparation meeting of the competition and before, during and at half time of the game. Fit Perform J 2008; 7(2):112-122.

11. Gilbert W, Trudel P, Gaumond S, Larocque L. Development and application of an instrument to analyse pedagogical content interventions of ice hockey coaches. Social Sport J 1999; 2(2).

12. Murcia JAM. Development and preliminary validation of an aquatic competence scale for children 4 to 11 years old. Rev Int Cienc Deporte 2005, 1(1):14-27.

13. Varveri D, Flouris A, Smirnios N, Pollatou E, Karatzaferi C, Sakkas G. Developing and testing an instrument to assess aquaticity in humans. J Bodyw Mov Ther 2016, 20(3).

14. Canossa S, Fernandes RJ, Carmo C, Andrade A, Soares SM. Multidisciplinary teaching in swimming: methodological reflection and proposal of check list. Motrici 2007, 3(4): 82-99.

15. Shulman LS. Paradigms and research programs for the study of teaching. In: Wittrock MC. Handbook of research on teaching. Barcelona: Paidós/MEC; 1989. 9-91.

16. Ward P. The role of content knowledge in conceptions of teaching effectiveness in physical education. Res QExerc Sport 2013; 84(4):431-440.

17. Hernandez-nieto RA. Data collection instruments in social sciences and biomedical sciences. Mérida: Universidad de Los Andes; 2011.

18. Pires NCM, Arantes EC, Silva WV, Kato HT. Differences and similarities in sampling techniques of top-of-mind researches: a comparative study. Rev Bras Gest Neg 2006; 8(22):37-45.

19. Balbinotti MA, Benetti C, Terra PRS. Translation and validation of the GrahamHarvey survey for the Brazilian context. Int J Manag Finance 2006; 3(1):26-48.

20. Ugrinowitsch H, Benda RN. Contributions from motor learning: the practice in Physical Education intervention. Rev Bras Educ Fís Esporte 2011; 25:25-35.

21. Tabachnick B, Fidell L. Using multivariate statistics. 6. Ed. Boston: Pearson, 2012.

22. Pečaver A, Pungersek M, Videmsek M, Karpljuk D, Stihec J, Mesko M. Analysis of didactic approaches to teaching young children to swim. Sport J 2014; 17.

23. Vancini RL, Castardeli EC, Sarro KJ, Fachina RJFG, Andrade MS, Lira CAB. Pedagogical techniques to teaching team and individual sports: a theoretical essay. Conexões 2015; 13(4):137-154. 
24. Fortes LS, Ferreira MEC, Polisseni MLC. Association between preferences of aquatic facilities and swimming activities for late childhood children. FIEP bull 2011; 81(1):01-07.

25. Aburachid LMC, Greco PJ. Scene content validation in a tactical knowledge tet of tennis. Estud Psicol 2011; 28(2):261-267.

26. Morales JCP, Greco JP, Andrade RL. Content validity of the instrument for assessment of the tactical procedural knowledge in basketball. Cuad Psicol Deporte 2012 12(1):31-36.

27. Greco PJ, Morales JCP, Aburachid LMC, Silva SR. Validity evidence of procedural tactical knowledge test for sports guidance. Rev Bras Educ Fís Esporte 2015; 29(2):313-324.

28. Pedrosa, G. F, Soares YM, Gonçalves R, Couto BP, Dias RA, Costa VT, et al. Content validation of a catalog of exercises for judô. Percept Mot Skills 2016; $0(0): 01-23$.

29. Landis J, Koch GG. The measurements of agreement for categorical data. Biometrics 1977; 33(3):159-179.

30. Brazil. Ministry of Sports. National Diagnosis of Sports - Diesporte. Caderno 2. Brasília, 2016.

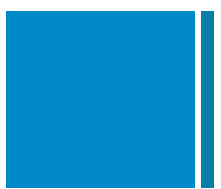

Corresponding author

Gabriella Nelli Monteiro

Rua Dr. Euricles Mota, 130 - Bairro Jardim Guanabara, CEP: 78010-715.

Cuiabá, Mato Grosso - Brazil.

E-mail: gnm_cba@hotmail.com 


\section{APPENDIX 1}

Instrument to assess organizations and types of practice and pedagogical feedback

Name of professor:

Class number: Local: Level of students:

Date: 1

Note for data inclusion: Insert the frequency of occurrence based on the action per activity of an instructor viewed in a filmed class.

To facilitate the observation of actions, it is possible to use the software MatchVision Studio Premium (CASTELLANO; PEREA; ALDAY, 2005) which connects the video to the screen as well as the variables at the same time.

\begin{tabular}{|c|c|c|c|c|c|c|c|}
\hline & & & Activity 1 & Activity 2 & Activity 3 & Activity 4 & Activity ... \\
\hline \multirow{2}{*}{\multicolumn{2}{|c|}{ Nature of the task }} & \begin{tabular}{|l|} 
Technique \\
\end{tabular} & & & & & \\
\hline & & Physical and rules & & & & & \\
\hline \multirow{18}{*}{ Pedagogical Feedback } & \multirow{6}{*}{ Objective } & Prescriptive & & & & & \\
\hline & & Descriptive correction & & & & & \\
\hline & & \begin{tabular}{|l|} 
Descriptive error \\
\end{tabular} & & & & & \\
\hline & & Evaluative positive & & & & & \\
\hline & & Evaluative negative & & & & & \\
\hline & & Interrogative & & & & & \\
\hline & \multirow{7}{*}{ Type } & Kinesthetic & & & & & \\
\hline & & Visual & & & & & \\
\hline & & Verbal & & & & & \\
\hline & & Verbal/ Visual & & & & & \\
\hline & & Verbal/Kinesthetic & & & & & \\
\hline & & Visual/Kinesthetic & & & & & \\
\hline & & Verbal/ Visual /Kinesthetic & & & & & \\
\hline & \multirow{3}{*}{ Direction } & Individual & & & & & \\
\hline & & In pair & & & & & \\
\hline & & In group & & & & & \\
\hline & \multirow{2}{*}{ Criterion } & Performance criterion & & & & & \\
\hline & & Result criterion & & & & & \\
\hline \multirow{4}{*}{\multicolumn{2}{|c|}{ Organization of practice }} & As a block & & & & & \\
\hline & & In a series & & & & & \\
\hline & & Varied & & & & & \\
\hline & & Constant & & & & & \\
\hline \multirow{4}{*}{\multicolumn{2}{|c|}{ Types of practice }} & As a whole & & & & & \\
\hline & & Fractioned & & & & & \\
\hline & & Segmented & & & & & \\
\hline & & Simplified & & & & & \\
\hline
\end{tabular}

